\title{
フリーアクセスフロアの耐震性評価用入力波の設定 \\ フリーアクセスフロアの耐震性の簡易評価方法に関する基礎的研究 \\ CONFIGURATION OF INPUT WAVE FOR EVALUATING SEISMIC RESISTANCE ON FREE-ACCESS FLOOR \\ Fundamental study on evaluation method for seismic resistance of free-access floor
}

\author{
横 山 裕*1, 片木詩子*2, 横井 健*3, 小野英 哲*4 \\ Yutaka YOKOYAMA, Utako KATAGI, Takeshi YOKOI \\ and Hidenori $O N O$
}

\begin{abstract}
This study aims at configuring the input wave, as a substance, so as to evaluate the seismic resistance of free-access floors. Approach used in this study is described in procedural manner as follows; At first, the behavior of specimen is observed, imputing real seismic waves, which is picked up on behalf of free-access floors. Next, as abstracted parts impacting the behavior of specimen by real seismic waves, input waves are obtained. And then, simple vibration table is made to reproduce input waves. Finally, it is configured that an input wave for evaluating the seismic resistance of free-access floors, substituted for real seismic waves.
\end{abstract}

Keywords : Free-access Floor, Seismic Resistance, Evaluation Method, Input Wave, Vibration Table フリーアクセスフロア, 耐震性, 評価方法, 入力波, 振動台

1.はじめに

電気機器や通信機器のための各種配線などを床下に収納し、任意の 場所で適宜取り出せるように工夫したフリーアクセスフロアは、近 年、我が国のオフィスなどで、林下地(おもにコンクリートスラブ)と 仕上げ(おもにタイルカーペット)の間に設けられる中間層として、多 用されている。現在、フリーアクセスフロア(以降、FAと記す)には、 様々なタイプがあり、今後もさらに多様化することが予想される。

ここで、床は、建筑物内での人々の活動を支える基盤となる部位で あることから、非構造部材であるFAに関しても、地震時に最低限、休 上の人間が安全に避難できるだけの安全性を確保する必要があると考 えられる。しかし、FAの耐震性に関する試験方法が明確な工学的根 拠に基づいて規定された公的規格はみあたらない。そのため、FAの 耐震性の検討にあたっては、現在、静的な水平荷重に対する耐力を実 験的，解析的に求める方法や、振動台を用いて特定の実地震波や振動 数を連続的に変化(スイープ)させた正弦波を入力し挙動を観察, 測定 する方法などがよく用いられている。しかし、前者は、動的な特性を 検討するうえで必ずしも実状に即しているとはいいがたく、また後者 は、一般性，簡便性の観点から改善の余地があるといえる。

本報は、FAの耐震性を一般性，簡便性のある方法で動的に検討す
るのに用いる、正弦波を基本とした耐震性評価用入力波を設定した経 過，結果を述べるものである。なお、本報の一部は、日本建築学会大 会で発表している1),2)。

\section{2. 目的, 範囲}

本研究は、FAの耐震性の簡易評価方法の骨子となる、䩂震性評価 用入力波を設定することを目的とする。

FAの䩂震性の萍価は、基本的に、実在する、あるいは今後開発さ れると思われる様々なタイプのもの全てが、共通の方法でなされる心゙ きと考えられる。また、耐震性には、パネルや支柱など FAを構成す る各部材の強度だけでなく、接合部のディティールなど種々の要因が 複雑に影響する。このことは、FAの地震時の挙動を解析的に予測し たり静的な実験により把握するのは困難であること、およびパネルや 支柱などFAの構成部材の一部を取り出したり根拠なく簡略化, 標準 化することなどは避け、実際に床として使用に供される状態、すなわ ち有り姿のFAの評価ができるようにする必要があることを意味して いる。しかし、有り姿のFAの耐震性を実験的かつ動的に検討する場 合、現状では、比較的高価な振動台を用い、大規模な実験を実施しな ければならない。このため、地震国である我が国でありながら、FA
*1 東京工業大学大学院理工学研究科建築学尃攻 助教授・丁.博

*2 東京工業大学大学院 修士 (工学)

*3 東京工業大学大学院 21 世紀 COE 研究員 $(\mathrm{PD}) \cdot$ 博士 (工学)

*4 束京工業大学 名誉教授，東北工業大学建築学科 教授・土博
Assoc. Prof., Dept. of Architecture and Building Eng., Graduate School of Science and Eng., Tokyo Institute of Technology, Dr. Eng. Graduate School, Tokyo Institute of Technology, M. Eng. 21st Century COE Postdoctoral Fellowship, Tokyo Institute of Technology, Dr. Eng.

Prof., Dept. of Architecture, Tohoku Institute of Technology, Dr. Eng. 
の耐震性の評価は、あまり一般的になされていないのが現状である。 本研究では、FA の耐震性の評価をより一般的にするうえで必要な、 比較的安価でかつ簡単な構造の振動台でも再現可能な入力波を設定す る。また、本研究では、設定した入力波を再現し、比較的小規模な実 験でFAの耐震性を簡易に評価できる振動台の設計，試作も、あわせ て行う。

なお、実在するFAの耐震性の具体的な評価は、本研究の範囲外と する。

\section{3. 既往の研究}

FAの耐震性の評価方法に関する研究例は、本研究の一部を速報し た筆者らの報告 ${ }^{12,2)}$ 以外見あたらない。

また、現在、FAの耐震性の評価方法を規定した公的規格としては、 国内外を通して、社団法人公共建築協会の建築材料・設備等機材品質 性能事業に保わる評価基準(平成 11 年版)3)が挙げられるのみである。 この規格では、固定台による利震性能試験(水平加力試験)と振動台に よる耐震性能試験の 2 種の試験方法が規定されている。前者は、FA の支柱頂部を静的に水平加力した際の挙動を観察, 測定するものであ

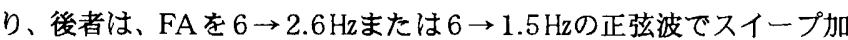
振した際の挙動を観察, 測定するものである。どちらの試験方法を適 用するかは、FAの設計床高さと構法により定められている。しかし、 これらの試験方法の設定経緯や工学的根执は明らかにされておらず、 現段階ではあくまでも暫定的な規格と位置付けるのが適当と考えられる。

一方、現在製品化されているFAの一部では、施主などの要求に応 じて、上記公共建築協会評価基準などを参考に、支柱頂部に水平荷重 を与えた際の静的挙動や、実地震波あるいは正弦波に対する動的挙動 に関する検討が独自になされており、個々には比較的多くのデータが 蕃積されているものと思われる。しかし、一連の結果が体系的に報告 された例は見あたらないため、これらの検討結果を本研究に直接適用 することはできない。

\section{4. 研究方法}

本研究の研究方法，手順は、以下の通りである。

(1)耐震性を検討するうえで代表的と思われるFAを、試験体として選 定する。つぎに、既存の油圧式振動台を用いて、選定した試験体に 実地震波などを入力し、試験体の挙動を観察，測定する。

(2)(1)の結果を参考に、実地震波などのうち試験体の挙動に大きく影響 すると思われる部分を抽出し、これを簡略化した簡易入力波を設定 する。

(3)(2)で設定した簡易入力波を再現できる、比較的簡単な構造の簡易振 動台を設計，試作する。

(4)(3)で設計，試作した簡易振動台を用いて、(1)で選定した試験体に(2) で設定した簡易入力波を入力し、試験体の挙動を観察，測定する。 (5)(4)と(1)の結果を比較し、簡易入力波で実地震波などによる試験体の 挙動を代替できることを確認したうえで、(2)で設定した簡易入力波 を耐震性評価用入力波として設定する。また、(3)で設計，試作した 振動台を、FAの耐震性の簡易評価に用いる振動台として例示する。

\section{5. 実地震波などによるフリーアクセスフロアの挙動の把握 5.1 試験概要}

\subsection{1 試験体}

図ー 1 に選定した試験体の概要を、また図ー 2 に断面詳細を示す。 本試験体は、1本の支柱に4枚のパネルの角部を載せる、いわゆる「独 立支柱タイプ」のものである。ここで、独立支柱タイプの FAを選定 したのは、FA を構成する部材数が多く耐震性の観点から弱点となり やすい接合部などが比較的多く存在することと、独立支柱夕イプ 2 種、置敷タイプを含む他のタイプ 4 種の FA に代表的な実地震波(El centro(NS), Taft(EW))を入力し挙動を観察した予備実験の結果、独 立支柱タイプが他のタイプより小さい入力で異状が発生したり破壊し たことによる。

試験体のパネルは鋼製の中空パネルで、1 枚の大きさは FA として

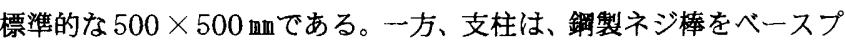
レートに溶接したもので、頂部には円板形で突起の付いた台座が取り 付けられており、この突起にパネルの角部を引っかけて固定する仕組 みとなっている。パネル上には、この種の床で一般的な厚さ $6.5 \mathrm{~mm}$ (公 称)のタイルカーペットを、接着せずに數くこととした。また、床下地 上端から仕上げ上端までの高さは、150 m ジ棒の太さは、実際に製品化されているこの種のFAではM16(直径約 $16 \mathrm{~mm}$ )以上が一般的であるが、本試験体では M8(直径約 $8 \mathrm{~mm}$ ) とした。 このように水平方向の強度を意図的に小さくした試験体を用いたの は、地震の影譬がより現れやすい試験体の方が、実地震波などと簡易
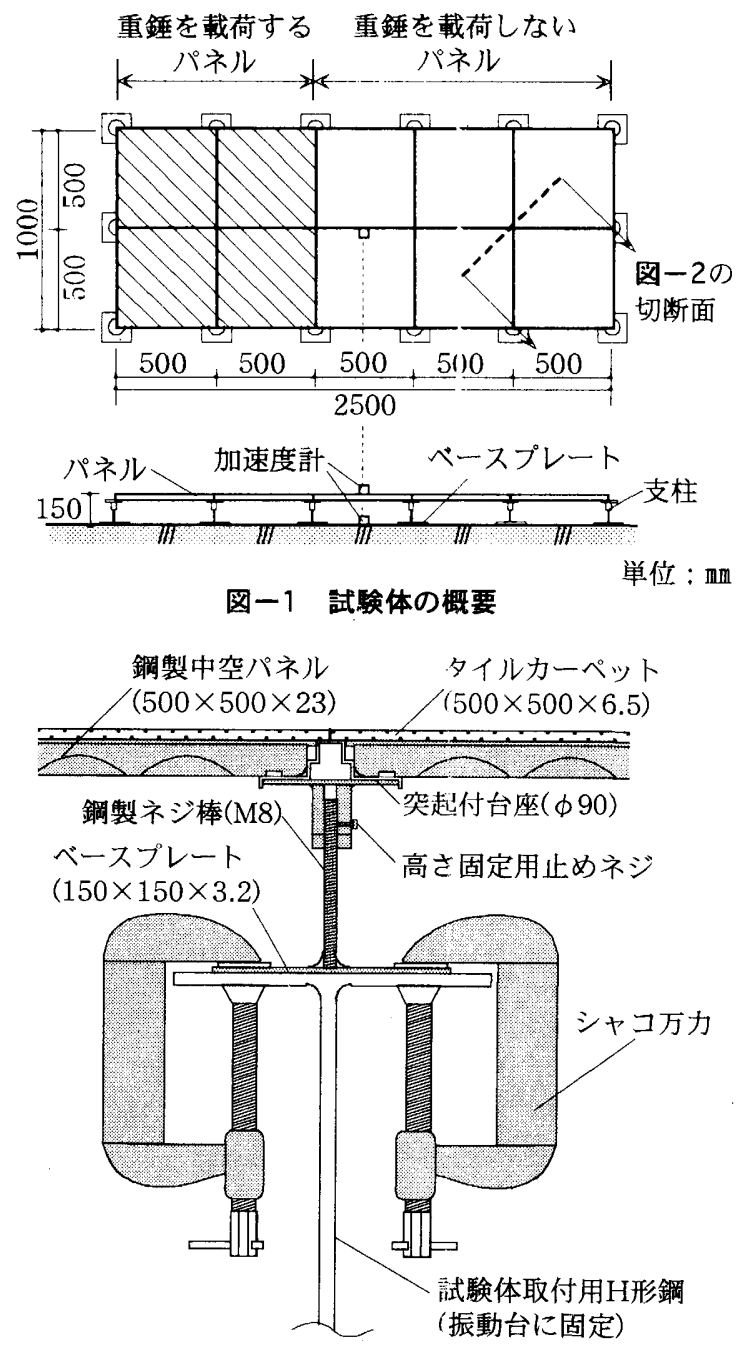

図一2，試験体の断面詳細

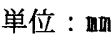


入力波に対する挙動の比較がしやすいことによる。なお、試験体を振 動台に設置する際は、図ー2に示すように、ベースプレートを振動台 に固定した試験体取付用H形鋼にシャコ万力で固定することとした。

試験体の大きさはパネル $2 \times 5$ 枚分とし、このうち一端の $2 \times 2$ 枚 のパネル上に5.1.2 で述べる重錘を載荷することとした。ここで、加 振方向のパネル枚数を 5 枚としたのは、重鍾の載荷されたパネルに続 いて載荷されていないパネルを 3 枚以上設置すれば、加振時に重鏵の 載荷されたパネルの影響により載荷されていないパネルが浮き上がる 現象などを十分再現できることが、同一のFA を用い、試験体の大き さをパネル $2 \times 3$ 枚分から $4 \times 5$ 枚分の範囲で種々変化させ、代表的 な実地震波(El centro(NS), Taft(EW))に対する挙動を観察した予備 実験の結果、明らかとなったことによる。一方、加振方向と直交する 方向のパネル枚数を重錘の載荷されている2枚のみとしたのは、この 方向に重鍾の載荷されていないパネルを続いて設置しても、加振時の 両者の挙動は独立性が高く互いにほとんど影響しあわないことが、上 述の予備実験の結果明らかとなったことによる。

なお、実際の建築物ではFAの周囲は壁などに突き合わせるのが一 般的であるが、本研究では、実地震波などと簡易入力波に対する試験 体の挙動の比較を目的としていることから、試験体周囲に挙動を拘束 するものは設置しないこととした。

\section{1 .2 重鍾}

図ー3に示す 2 種の重錘を、FA上に載荷することとした。ここで、 重錘の重量はそれぞれ $300 \mathrm{~kg} \mathrm{f}$ とし、図ー 1 に示すように $2 \times 2$ 枚の パネル $\left(1 \mathrm{~m}^{2}\right)$ 上に載荷することとした。これは、多くのオフィス用 $\mathrm{FA}$ が積載荷重 $300 \mathrm{~kg} \mathrm{f} / \mathrm{m}^{2}$ で設計されていることによる。

このうち脚付重鍾は、オフィスなどで一般的な什器, 備品のうち最
も重いものの 1 つであるコピー機を置換したもので、重量の効果に加 え、脚への荷重の集中やロッキングの影篔などを検討する目的で採用 したものである。脚の接地部分の形状は直径50mmの形(JIS A 14504) に規定された荷重試験の加圧子の底面と同一)であり、裹面にはすべり 止めが貼付してある。また、加振方向の脚間隔は700 眐、その直交方 向の脚間隔は 650 m nn ら開始し、100m間隔で徐々に狭くしながら、正弦波 $(2 \mathrm{~Hz})$ に対する脚 付重鍾の举動を観察した予借実験の結果に基づいて、300galを超える 程度の入力に対してロッキングが発生するよう設定したものである。 なお、脚付重錘の重心は床上から約 $650 \mathrm{~mm}$ の位置にあり、加振方向の 固有振動数は $5.0 \mathrm{~Hz}$ 、減衰定数は $2.1 \%$ である。

一方、平置重錘は、脚への荷重の集中やロッキングの影響などをで きる限り排除し、重量の効果のみを把握する目的で、探用したもので ある。なお、平置重錘の試験体上での静止摩擦係数は、0.74である。

\subsection{3 入力波}

FAが設置される床下地の地震時の応答波形は、大きく以下の 2 種 に分類できると考えられる。

(1) 10 階建て程度以下の中, 低層建築物 : 地盤上で測定される地震波 と近似

(2) 10 階建て程度以上の高層建築物 : 地震により励起される建築物の 水平方向の固有振動数での正弦波と近似

本研究では、このような考え方に基づいて、以下に示す 8 種の入力 波を設定した。

(1)中，低層建築物の床下地応答を模擬した入力波

$\mathrm{El}$ centro(NS), Taft(EW), 八戸(EW), 阪神(NS), 宮城沖(EW)の 5 種の実地震波。ここで、各実地震波の加速度波形に含まれる主要な

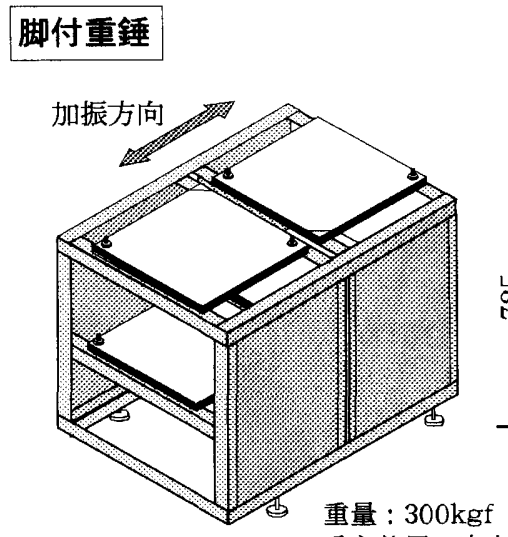

重心位置 : 床上約 $650 \mathrm{~nm}$

固有振動数 : $5.0 \mathrm{~Hz}$

減衰定数: $2.05 \%$

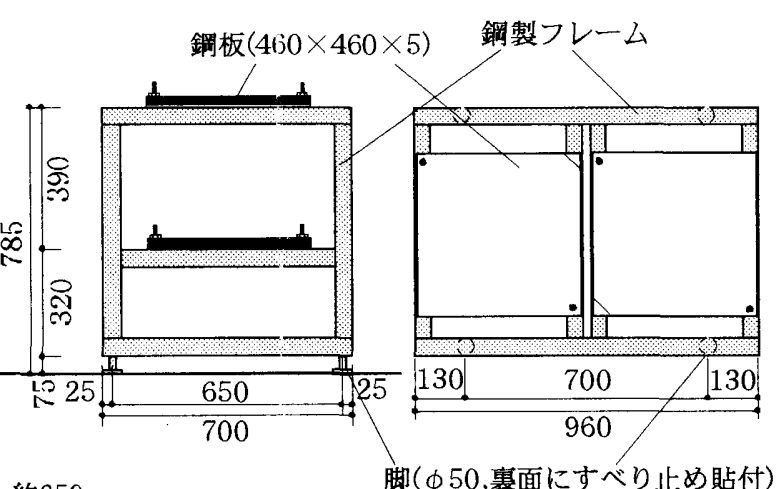

脚（ $\phi 50$,裏面にすべり止め貼付）

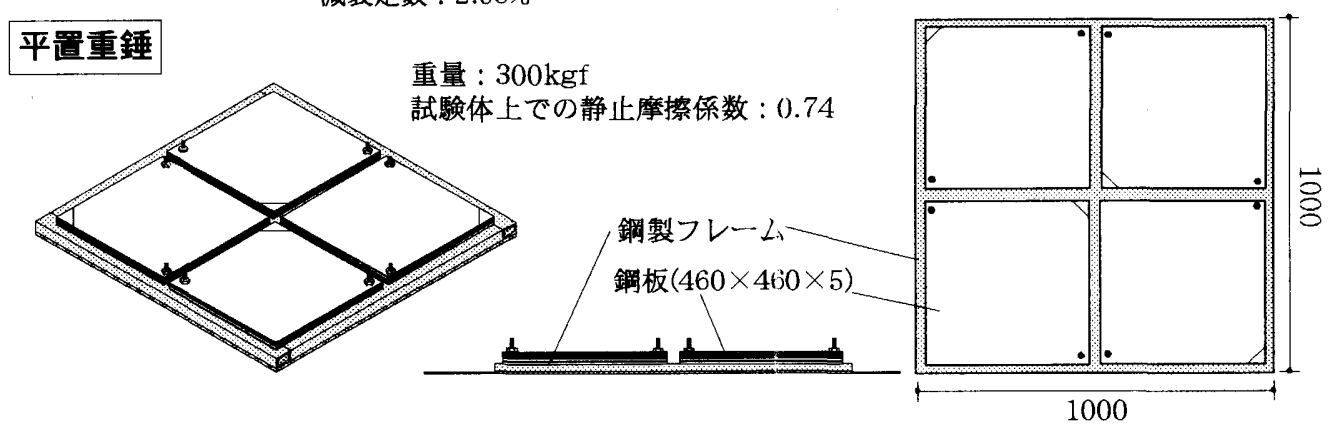

図一3 重錘の概要

単位 : mm 


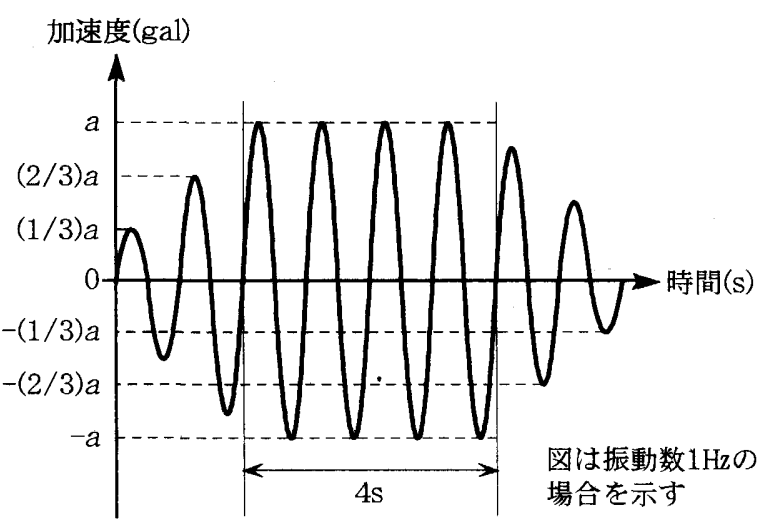

図一4 高原建築物の床下地応答を模擬した 入力波(模擬波)の概要

振動数成分は、El centro(NS)が $1.5 \mathrm{~Hz}$ を心に 1〜2 Hz程度、Taft (EW)が $1.75 \mathrm{~Hz}$ を心に $1 \sim 2.5 \mathrm{~Hz}$ 程度、八戸(EW)が $0.75 \mathrm{~Hz}$ を心 に $0.5 \sim 1 \mathrm{~Hz}$ 程度、阪神(NS)が $1.5 \mathrm{~Hz}$ を中心に $1 \sim 2 \mathrm{~Hz}$ 程度、宮城冲 (EW)が $2 \mathrm{~Hz}$ を心に 1 〜 $\mathrm{Hz}$ 程度である。

(2)高層建築物の床下地応答を模擬した入力波

図ー4に示す継続時間 4s の正弦波を主体とした入力波(以降、模擬 波と記す)。ここで、模擬波の振動数は、10３0階建ての建築物の水 平方向の固有振動数の簕囲をほほ包含するよう、0.5，1，2 $\mathrm{Hz}$ の 3 種 とした。正弦波の部分の継続時間を 4 s としたのは、固有振動数 $0.5 \sim$ $2 \mathrm{~Hz}$ 、隇衰定数 $2 \%(\mathrm{~S}$ 造で一般的な値) $5 \%(\mathrm{RC}$ 造で一般的な值)の範 囲内の種々の 1 自由度振動系に(1)で述べた 5 種の 実地震波を入力し応答解析した結果、応答波形の うち振幅が最大值に達した前後での正弦波に近似 した部分の継続時間はおおむね2〜 4s程度であっ たことによる。

\subsection{4 澌定項目}

加振時の試験体の挙動をビデオに記録するとと もに、試験体設置時、およびそれぞれの加振後に、 試験体の各支柱の水平変位、および各パネル間の 隙間を適宜測定することとした。ビデオは、試験 体全体が写るよう設置したもの 1 ～2台と、支柱 の挙動を記録する目的でパネルと振動台の間の空 間が写るよう設置したもの 2 台の、計 $3 \sim 4$ 台を 用いることとした。また、あらかじめ5名以上の 判定者を選定し、試験体の加振中の挙動や加振後 の状態の観察結果、および支柱の水平変位やパネ ル間の隙間の测定結果を参考に、総合的に異状な し，異状あり，破填の 3 段階の判定を合議により 下すこととした。さらに、図一1に示すように振 動台上および試験体上(FAのパネル上面に固定)に 加速度計を設置し、加振時の加速度・時間曲線を

\section{表ー 1 試験体の振動特性の範囲}

\begin{tabular}{|c|c|c|}
\hline & 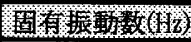 & 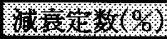 \\
\hline 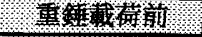 & $16.0 \sim 17.5$ & $6.3 \sim 8.5$ \\
\hline 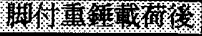 & $17.0 \sim 17.5$ & $3.2 \sim 4.3$ \\
\hline 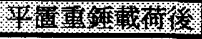 & $8.5 \sim 9.0$ & $4.0 \sim 5.4$ \\
\hline
\end{tabular}

測定することとした。

\section{2 試験経過}

試験は、財団法人建材試験センター中央研究所の油圧式振動台を用 い、2002 年 2 月に実施した。具体的には、以下の手順で実施した。 (1)振動台に試験体を設置し、試験体上に所定の重錘を載荷する。その

際、毎回同等の試験体が設置できているかどうかを確認する目的 で、設置した試験体の加振方向の振動特性を重鍾載荷前後で測定 し、重鍾載荷前同士、および後同士で固有振動数や減衰定数に大き な変化がないことを確認する。

(2)(1)で設置した試験体を、所定の入力波で加振する。はじめは、最大 加速度50〜150gal程度で加振し、試験体の挙動を観察, 測定する。 続いて、徐々に入力波の振幅を増加させ、試験体の挙動を観繁, 測定 する。この試験を、試験体が破壊するか、入力被の振幅が振動台の能 力上の最大振幅に達するまで行い、当該入力波での試験を終了する。 以上の試験を、 8 種の入力波と 2 種の重鍾の組み合わせ 16 種ごとに 実施した。なお、八戸 $(\mathrm{EW}), 0.5 \mathrm{~Hz}$ 模擬波, $1 \mathrm{~Hz}$ 模擬波の 3 種の入力 波では、振動台の能力上の最大振幅まで武験を行ったが、試験体が破 壊するにはいたらなかった。

\section{3 試験結果および考察}

表ー 1に、(1)で測定した試験体の振動特性の籁囲を示す。表より、 入力波, 重鏵ごとに設置した試験体の固有振動数，诚衰定数に大きな変 化はなく、毎回ほぼ同等の試験体が設置できていたことが確認できる。

図一5に、加振時に振動台上で測定された加速度振幅の最大值(実地 震波などの最大加速度)と、加振後の試験体の状態の判定結果の関係を
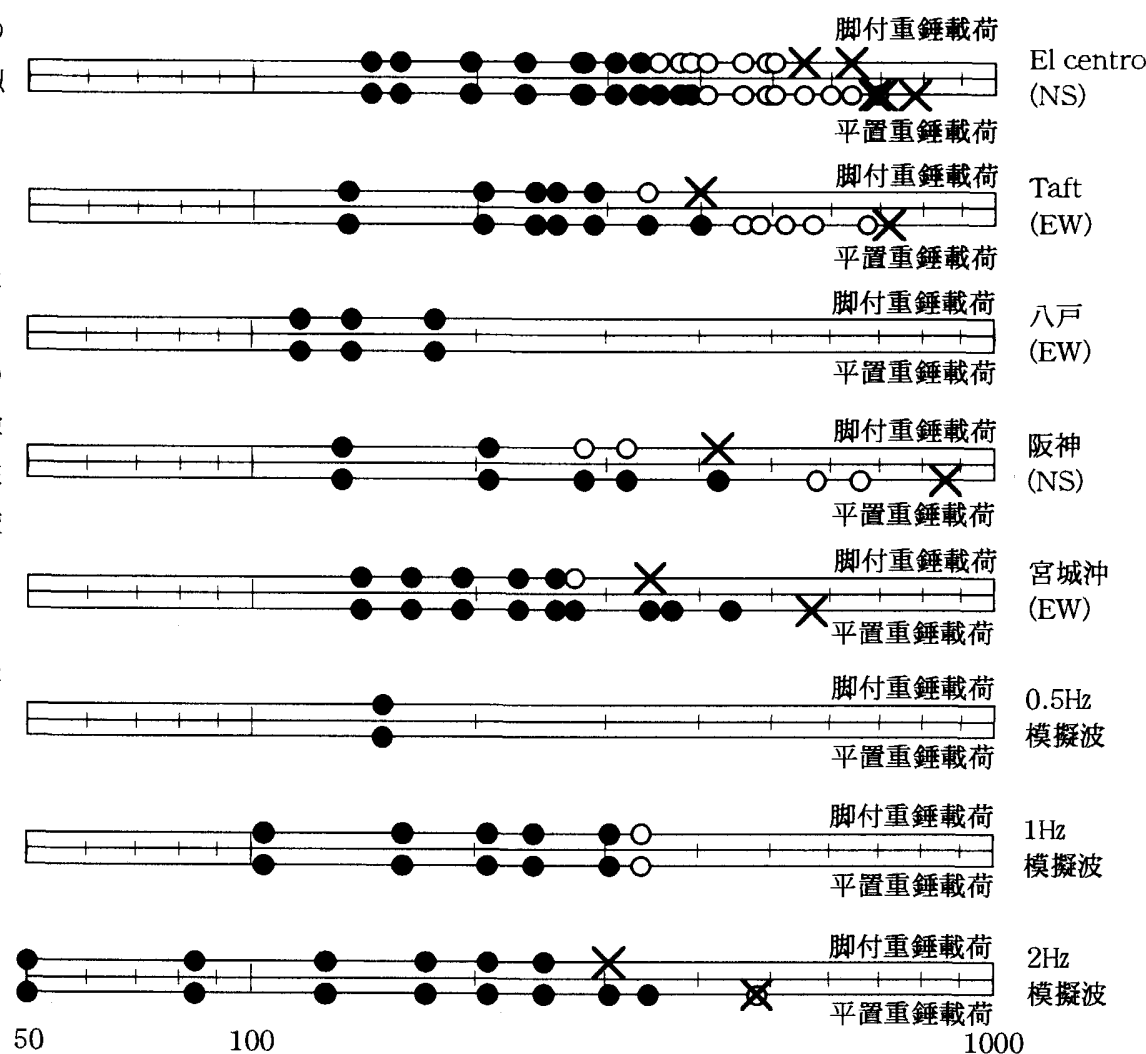

実地震波などの最大加速度(gal)

○：異状なし $\bigcirc$ : 異状あり X: 破壊

図-5 実地震波などの最大加速度と加振後の試験体の状態の関係 
示す。図より、大力波，重鉷ごとに、最大加速度 が大きくなるにしたがって判定結果が異状なしか らありに移行し、さらには破壊にいたる過程が読 みとれる。異状が発生しはじめる、あるいは破壊 にいたる最大加速度は入力波により異なってお り、波形の違いの影響がうかがえる。具体的には、 主要な成分が高振動数側にある入力波ほざ、異状 が発生しはじめる、あるいは破壊にいたる最大加 速度は小さくなる傾向がみられる。また、入力波 が同じ場合、脚付重錘載荷の方が平置重錘載荷よ り小さい最大加速度で、異状バ発生しはじめる、 あるいは破壊にいたっていることがわかる。

つぎに、図ー6に、実地震波などの最大加速度 と、試戨体設置時と加振後での支柱の水平変位の 差、およびパネル間の隙間の差(以降、“加振前後 での差”と記す)の関係を示す。図の維軸は、18 本の支柱ごとに測定した水平変位の差 18 テータ の最大値、および 13 箅所のパネル間ごとに測定 した隙間の差 13 データの最大值を表すもので、 記号は入力波の種類之異状の有無の判定結果に基 ゔいて分類したものである。なお、試験体が破壊 した場合のデー夕は除外してある。図より、最大 加速度が $300 \mathrm{gal}$ 程度以下の範囲では支柱の水平 変位の差は $0.5 \mathrm{~mm}$ 程度、パネル間の隙間の差は 1 mm程度となっているのに対し、300galを超える あたりから両者ともに大きくなり、あわせて試験 体の状態も異状ありと判定されていることがわか る。300gal を超えるあたりからの加振前後での 差の増加は、脚付重鍾載荷の場合、および平置重 錘載荷の場合の支柱の水平変位の差で特に顕著で ある。また、異状ありと判定された点からは、最 大加速度と加振前後での差の関係に入力波による 傾向をうかがうことができる。

一方、図一 7 に加振前後での支柱の水平変位 の差の最大値とパネル間の隙間の差の最大値の関 係を示す。図より、加振前後での差が図中に点線 で示す支柱の水平変位の差 $1 \mathrm{mn}$ とパネル間の隙間 の差2m的を結ぶ直線より左下側に位置する場合は おおむね異状なし、右上側に位置する場合はおお むね異状ありと判定されていることがわかる。

さらに、図一8に、実地震波などの最大加速度 と加振時に試験体上で測定された加速度振幅の最 大値(試験体の応答最大加速度)の関係を示す。図 より、両者の関係に入力波による明確な傾向はみ られず、振動台上から試験体上への最大加速度の増幅率は、波形の違 いによらずほぼ一定であることがわかる。入力波による傾向がみられ ないことは、本試験で用いた実地震波などでは、加振時に試験体の共 振現象などはほとんど発生していないことを示唆している。ここで、 本試験で用いた試験体は水平方向の㓮性を意図的に小さくしたものて あり、実在するFAの水平方向の固有振動数はより高いことから、実

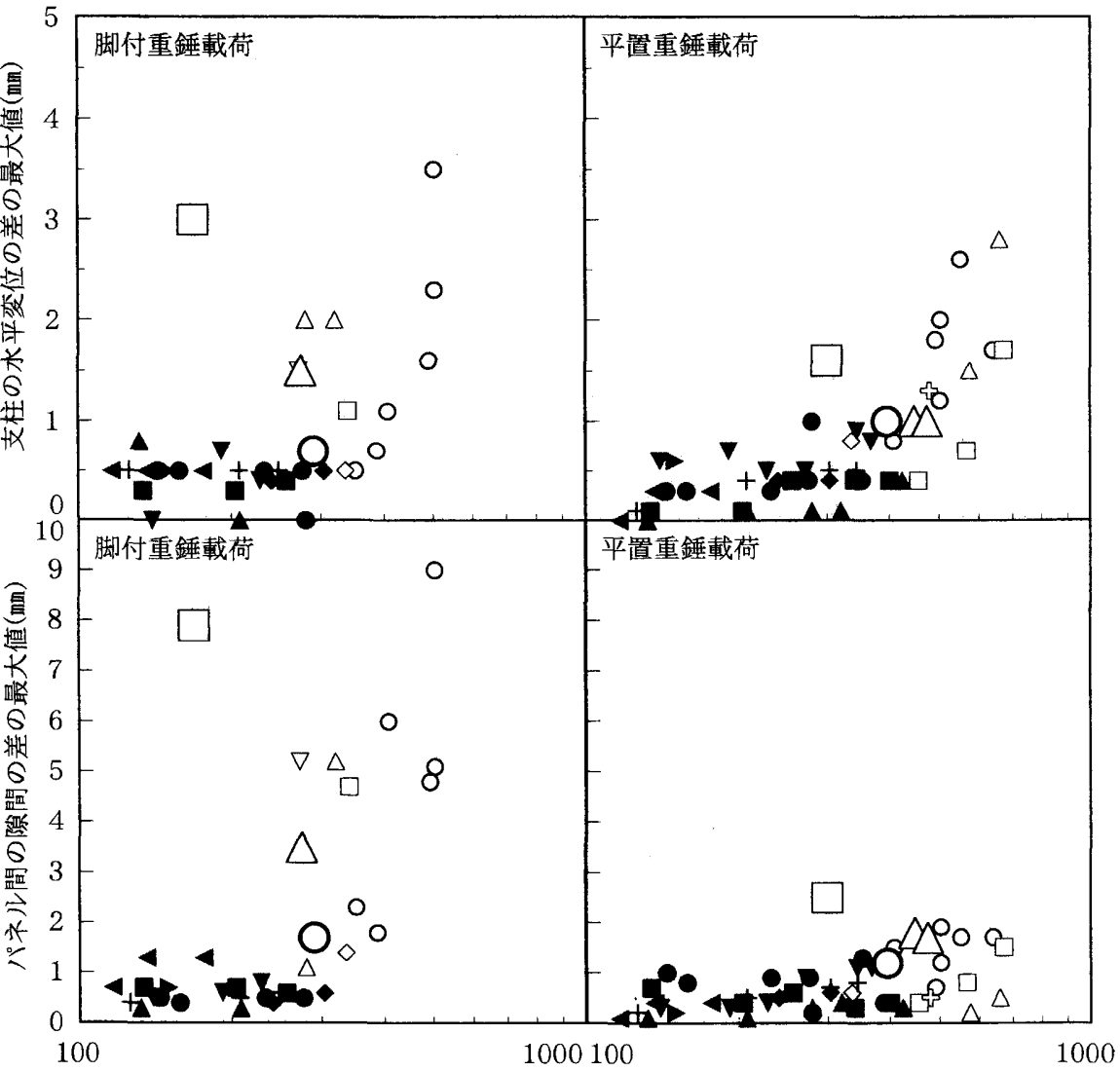

実地震波などの最大加速度または簡易入力波の加速度振幅(gal)

\begin{tabular}{|c|c|c|}
\hline \multicolumn{2}{|c|}{ 実地震波など } & 簡易入力波 \\
\hline 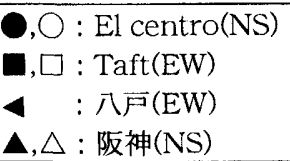 & 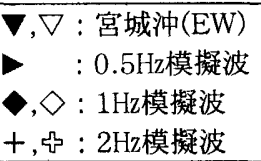 & $\square: 3 \mathrm{~Hz} 3$ 波 \\
\hline & 已号：異状なし，白 & 異状あり \\
\hline
\end{tabular}

図-6 実地震波などの最大加速度または简易入力波の加速度振幅と 加振前後での支柱の水平変位, パネル間の隙間の差の関係

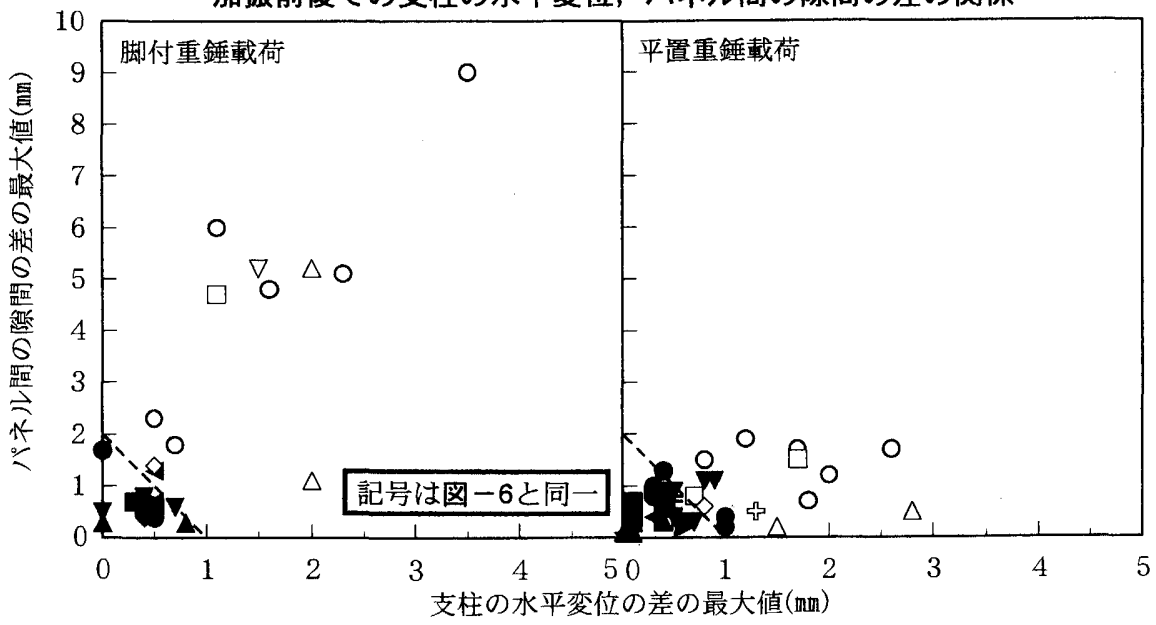

図-7 加振前後での支柱の水平変位の差とパネル間の隙間の差の関係

際の地震時に実在するFAで共振現象が発生する可能性は極めて低い ことが想定できる。

6. 簡易入力波の設定および簡易振動台の設計，試作

6.1 簡易入力波の基本構想

簡易入力波の設定にあたり、5. で実地震波などを入力した際の試 
験体の挙動を記録したビデオを、再度詳細に 検討した。その結果、試験体に加振後まで残留 する支柱の水平変位やパネル間の隙間が発生 したり、試験体が破壞したりするのは、実地震 波の加速度振幅が最大に達する時点(模擬波の 場合は最初に加速度振幅が最大に達する時点） 前後の比較的短い期間であり、加振中の比較 的長い期間に渡って徐々に支柱の水平変位や パネル間の隙間が増大したり、破壊が進行す るような現象はほとんどみられないことがわ かった。すなわち、FAの加振後の状態には、 実地震波などのうち加速度振幅が最も大きい 部分前後の数波が支配的に寄与することが想 定された。

以上より、図ー9に示すような、加速度振幅

$a$ ，振動数 $f$, 波数nの正弦波を基本とする簡易入力波を設定すること とした。この簡易入力波は、実地震波などのうち加速度振幅が最も大 きい部分前後の数波を、基本となる正弦波で置き換えることを意図し たものである。すなわち、最大加速度 $\mathrm{a}$ の実地震波などと、加速度振 幅aの簡易入力波によるFAの挙動を比較しようとするものである。基 本となる正弦波の前後には、加振開始時および終了時の衝撃を低減す る目的で、図に例示するように所定の過程を経て加速度振幅 $a$ ，振動 数 $f$ に達する前置波と、逆の過程を释て加振を終了させる後置波をつ なげることとした。なお、前置波，後置波の詳細は、6.2で述べる簡 易振動台の設計，試作の際にあわせて設定することとした。

\section{2 簡易振動台の設計，試作および簡易入力波の設定}

6.1 で述べた基本構想にそった簡易入力波を再現できる簡易振動台 を設計，試作した。図ー10に、簡易振動台の概要を示す。

本振動台は、平行に設置した 3 本のステンレス製レ一ル上を水平 1

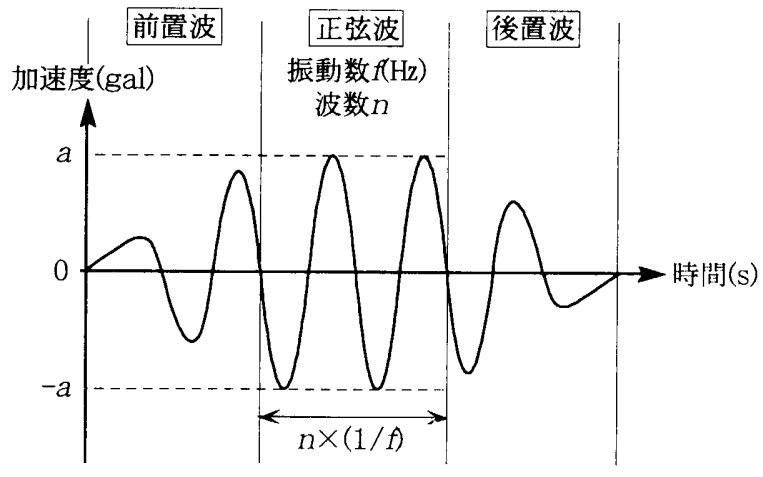

図一9 簢易入力波の基本構想

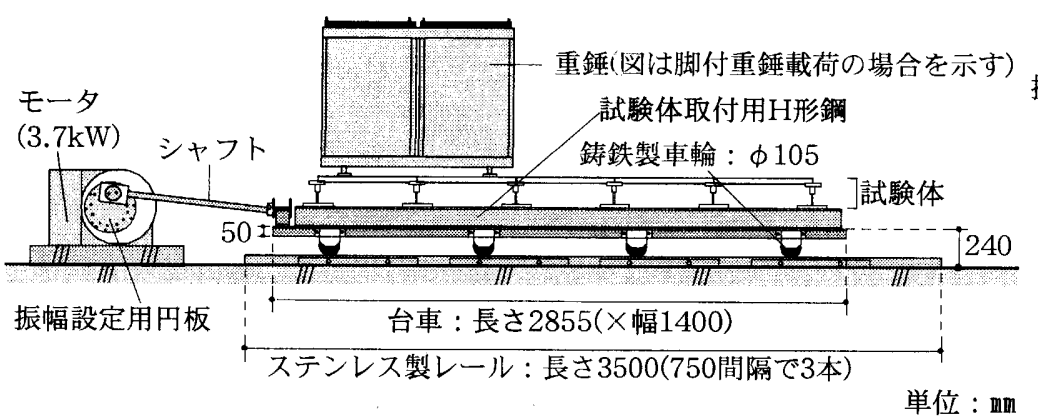

図-10 簡易振動台の概要
方向になめらかに動く台車と、この台車に所定の振動を発生させるた めのモータやシャフトなどからなる。台車は、12個の鋳鉄製車輪およ び鋼製アングルなどで構成されている。一方、モー夕は、十分な出力 $(3.7 \mathrm{~kW})$ を有する交流モータであり、プログラム制御機能付きイン バータにより回転数およびその時間変化を自由に制御することができ る。モータの回転軸には、振幅設定用円板が取り付けられている。こ の円板は、モータの回転軸と円板上のシャフトの取り付け位置との距 離を任意に設定できるよう工夫されたもので、モータの回転運動が円 板とシャフトからなるクランクにより台車の並進運動に変換される機 構となっている。すなわち、モータの回転軸と円板上のシャフトの取 り付け位置との距離が、台車の変位振幅となる。ここで、本振動台で 設定できる変位振幅の最大値は、5.の試験結果などを参考に、 $1 \mathrm{~Hz}$ も 400gal 程度の加速度振幅が得られるよう、100 㿼とした。

以上に述べた簡易振動台を用い、加速度振幅 $a$ ，振動数 $f$ の正弦波 を発生させるのに必要な変位振幅をあらかじめ振幅設定用円板で設定 したうえで、モータを回転させ、台車上に設置した試験体に簡易入力 波を入力することとした。ここで、モー夕の回転数の時間変化は、 種々検討の結果、図一 11 に示すように、前置波(後置波)の継続時間 $t$

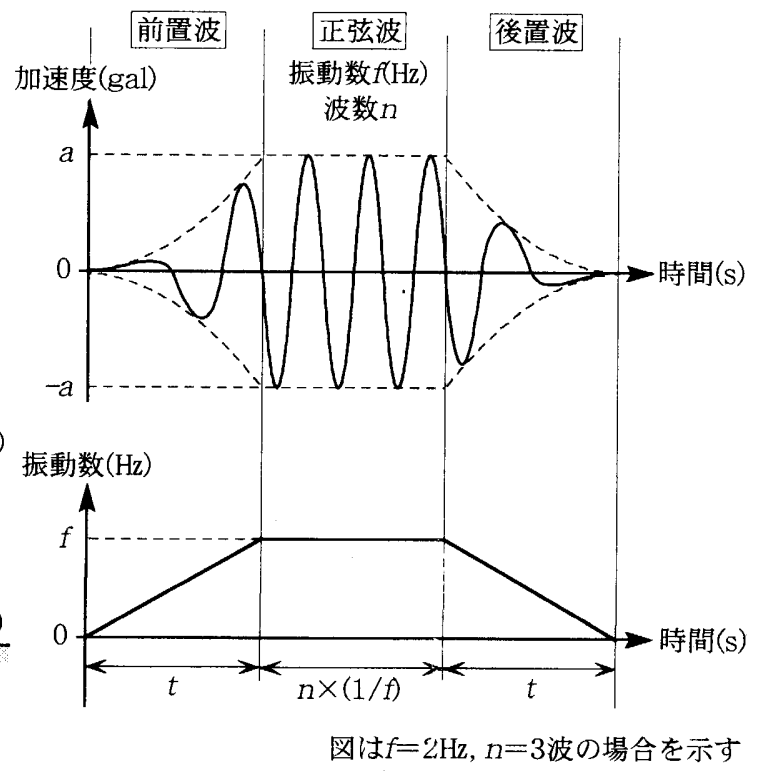

図-11 簡易入力波の概要 
の間に振動数が 0 から $f(f か ら 0) に$ 直線的に増加(減少)するよう設定し た。この結果、变位振幅が一定であることから、加速度振幅は、図に 示すように、継続時間 $t$ の間に 0 から $a(a$ から 0$) に 二$ 次関数的に增加 (減少)することとなる。本研究では、この入力波を簡易入力波として 設定した。

\section{7. 簡易入カ波によるフリーアクセスフロアの挙動の把握 7.1 試験概要}

6. で設計，試作した簡易振動台を用い、5. で選定した試験体に6. で設定した簡易入力波を入力した際の挙動を観察, 測定することとし た。測定項目は、基本的に5.1.4で述べたと同様としたが、支柱の水 平变位, パネル間の隙間の測定は、加振後の試験体の状態が目視や代 表的ないくつかの点での測定結果から明らかに異状なしと判定できる 場合は省略した。

簡易入力波の振動数 $f$ は、 5. の試験結果に加㫕、実地震波に多く含 まれる振動数成分の範囲などを考慮し、とりあえず $1 ， 2 ， 3 \mathrm{~Hz}$ の 3 種 とした。また、波数nは、5.3で述べた通り、実地震波などでの加振 時に試験体の共振現象などはほとんど発生していなかったことから、 比較的少ない波数で十分と考え、とりあえず $1 ， 2 ， 3$ 波の 3 種とした。 すなわち、 $f$ との組み合わせ 9 種ごとに、加速度振幅 $a$ を徐々に大 きくしながら試験体の挙動を観察, 測定し、実地震波などとの関係を 検討することとし、十分な対応が得られない場合には、さらに他の $f$,
一致する。

・簡易入力波の振動数で比較すると、 $1 \mathrm{~Hz}$ より $2 \mathrm{~Hz} 、 2 \mathrm{~Hz}$ より $3 \mathrm{~Hz}$ の 方が、小さい加速度振幅で異状が発生しはじめる、あるいは破壊に いたる傾向が把握できる。すなわち、実地震波などを対象とした場 合と同様の傾向が把握できる。

・簡易入力波の波数で比較すると、平置重鍾載荷の場合の $3 \mathrm{~Hz} 1$ 波之 2 波で結果に若干の違いがみられるが、全体的にみて大きな違いは ないとみなすことができる。このことから、波数が4波以上の場合も、 結果に大きな違いは生じないと想定できる。

つぎに、図ー12と、実地震波などによる試験結果を示した図ー5の 比較から、以下の事項が考察できる。

・実地震波などの中で、比較的小さい最大加速度で異状が発生しはじ める、あるいは破壊にいたっているのは、5.3で述べた通り、主要な 成分が高振動数側にある宮城沖(EW)と $2 \mathrm{~Hz}$ 模擬波である。また、こ れらの最大加速度と近似した加速度振幅で異状が発生しはじめる、 あるいは破壊にいたっている簡易入力波は、 $2 \mathrm{~Hz}$ の簡易入力波であ る。すなわち、 $2 \mathrm{~Hz}$ の簡易入力波で異状が発生しはじめる、あるい は破壊にいたる加速度振幅は、実地震波などにより異状が発生しは じめる、あるいは破壊にいたる最大加速度の範囲の下限にほぼ近似 しているとみなすことができる。これに対し、 $1 \mathrm{~Hz}$ の簡易入力波で 異状が発生しはじめる、あるいは破壊にいたる加速度振幅は実地震 波などによる最大加速度の範囲の下限より大きく、逆に $3 \mathrm{~Hz}$ の簡易 nでの検討を行うこととした。なお、前置波, 後置 波の継続時間 $t$ は、1.5，3.0，6.0s の 3 段階設定し、 代表的な簡易入力波 $(2 \mathrm{~Hz} 3$ 波)に対する脚付重鍾を 載荷した試験体の挙動を観察した予備実験の結果、 異状が発生しはじめる、あるいは破壊にいたる加速 度振幅はほとんど変化しなかったことから、 $1.5 \mathrm{~s}$ と した。

\section{2 試験経過}

試験は、2002年8月に実施した。試験の具体的な 手順は、5.2で述べたと同様である。試験は、9種の 入力波と 2 種の重鍾の組み合わせ 18 種ごとに実施 した。なお、振動数が $1 \mathrm{~Hz}$ の簡易入力波で平置重鏵 載荷の場合は、簡易振動台の能力上の最大振幅まで 試験を行ったが、試験体が破壊するにはいたらなかっ た。

\section{3 試験結果および考察}

簡易入力波の入力に先立ち、試験体の加振方向の 振動特性を測定した結果、固有振動数，減衰定数は 表ー 1 に示した範囲内であり、本試験でも毎回ほぼ 同等の試験体を設置していたことが確認できた。

図ー12に、加振時に振動台上で測定された加速度 振幅の最大値(簡易入力波の加速度振幅)と、加振後 の試験体の状態の判定結果の関係を示す。図より、 以下の事項が考察できる。

・簡易入力波が同じ場合、脚付重錘載荷の方が平置 重錘載荷より小さい加速度振幅で、異状が発生し はじめる、あるいは破壊にいたっている。この結 果は、5. で述べた実地震波などによる試験結果と

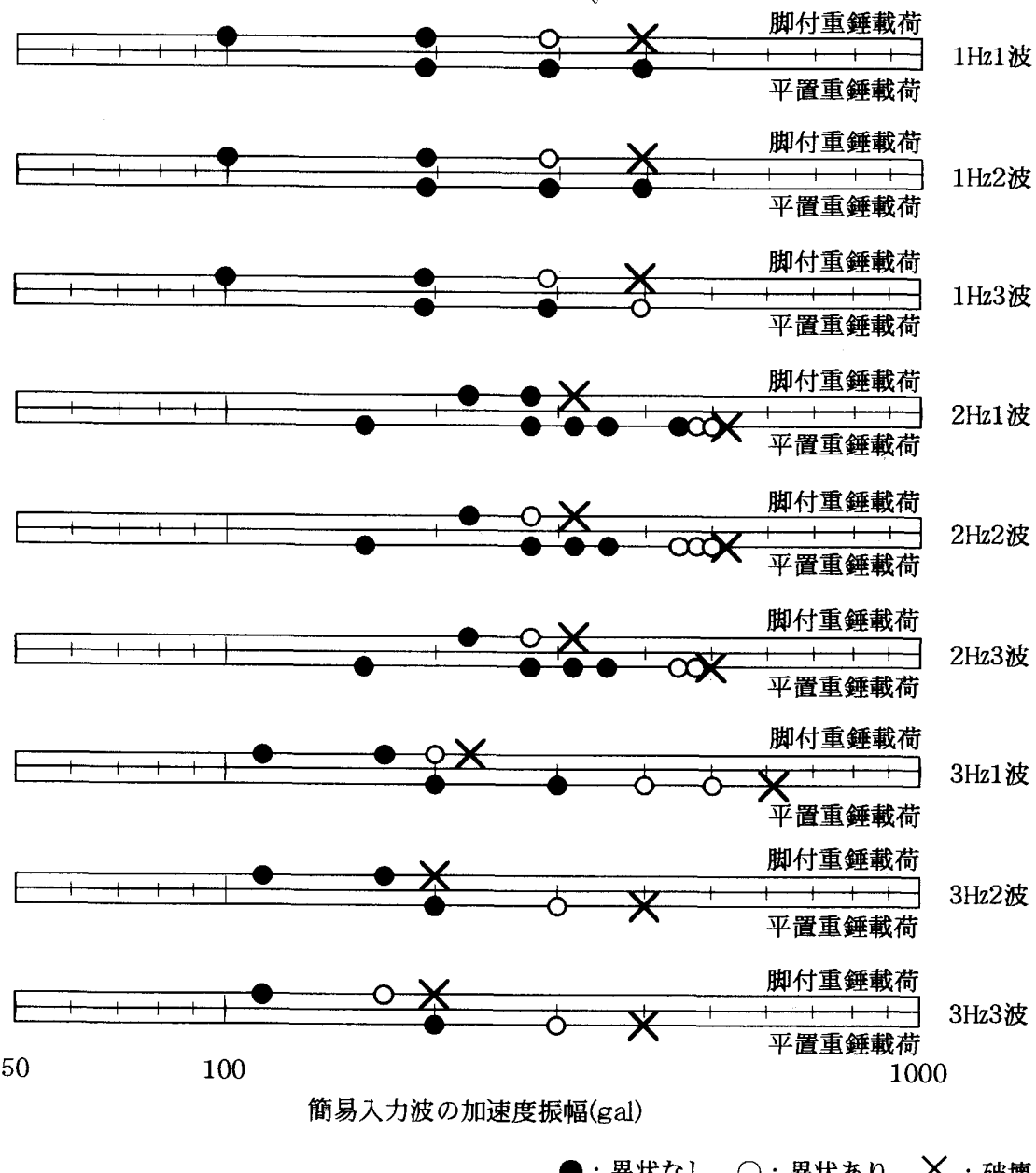

図-12 簡易入力波の加速度振愊と加振後の試験体の状態の関係 
入力波では小さい。

以上をまとめると、耐震性評価用入力波として $1 \mathrm{~Hz}$ の簡易入力波は 加振力が過小、 $3 \mathrm{~Hz}$ は過大であり、 $2 \mathrm{~Hz}$ の簡易入力波の加振力が適切 であること、波数については、1 波と 2 波で結果に若干の違いが生じ る場合があるが 2 波以上では大きな違いは生じず、安全をみて 3 波入 力すれば十分であることがわかる。すなわち、 $2 \mathrm{~Hz} 3$ 波の簡易入力波 が、耐震性評価用入力波として最も適当とみなせることがわかる。

ちなみに、実地震波を用いてFAの耐震性を検討する場合、その波 形に含まれる主要な成分が比較的高振動数側にあることを確認したう えでないと、安全側の評価を得る観点から、一般性のある評価は得ら れないといえる。また、3. で述べた既往の試験方法の1つであるFA を $6 \rightarrow 2.6 \mathrm{~Hz}$ または $6 \rightarrow 1.5 \mathrm{~Hz}$ の正弦波でスイープ加振する方法は、振 動数成分の観点から入力が過大であることが想定できる。

さらに、以上の考察結果を確認する目的で、実地震波などの最大加 速度と加振前後での支柱の水平陙位, パネル間の隙間の差の最大値の 関係を示した図一 6 に、 $1 \mathrm{~Hz} 3$ 波, $2 \mathrm{~Hz} 3$ 波, $3 \mathrm{~Hz} 3$ 波の簡易入力波で

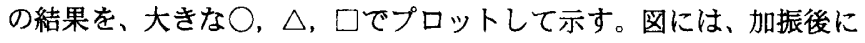
異状ありと判定された場合の、簡易入力波の加速度振幅と、支柱の水 平変位, パネル間の隐間の差の最大值の関係を示した。図に示す通 り、重鍾の種類にかかわらず、2 $\mathrm{Hz} 3$ 波簡易入力波による $\Delta$ は実地震 波などによる支柱の水平変位, パネル間の弥間の差の最大值の分布の 上限近傍にプロットされているのに対し、 $1 \mathrm{~Hz} 3$ 波簡易入力波による ○はより下方、 $3 \mathrm{~Hz} 3$ 波簡易入力波による口はより上方にプロットさ れており、それぞれ加振力が過小，過大であることを裹付ける結果と なっている。

また、実地震波などの最大加速度と試験体の忘答最大加速度の関係 を示した図ー8に、1 Hz 3 波， $2 \mathrm{~Hz} 3$ 波，3Hz 3 波の簡易入力波での結 果をプロットして示す。図より、脚付重鍾載荷, 平置重錘載荷のいず れの場合も、1，2Hzの場合は振動台上から試験体上への增幅率が実地 震波などと同程度であるのに対し、3Hzの場合はやや大きくなってお り、試験体の共振現象が現れ始めていることがわかる。すなわち、本 試験では水平方向の用性を意图的に小さくした試験体を用いたため、 $3 \mathrm{~Hz}$ の場合、主要な成分が高振動数側にあることの直接的な影響のみ でなく、これに共振現象が現れ始めることの影䈏が重なって、異状が 発生しはじめる、あるいは破壊にいたる最大加速度が小さくなったも のとみなせる。

\section{8. 耐㞼性評価用入力波の設定}

前章までの検討結果より、 $2 \mathrm{~Hz} 3$ 波の簡易入力波を、実地震波など によるFAの耐震性を安全側に包含する形で評価できる耐震性評価用 入力波として設定する。また、6.2で設計，試作した簡易振動台を、FA の耐震性の簡易評価に用いる振動台として例示する。

ここで、設定した入力波は、どのような波形の地震が発生するか予 想できない状況を想定し、かつ簡便さも考慮して、安全側の評価を与
える1種を共通の入力波として設定したものであり、対象とする実地 震波などによっては過大な入力となる可能性があることに、留意が必 要である。

なお、本研究では 1 種のFAのみを用いた検討結果から入力波を設 定したが、5.3で述べた通り、実際の地震時に実在するFAで共振現象 が発生する可能性は極めて低いと想定されることから、得られた結果 は一般的な範囲ではFAの振動特性により大きく変化するものではな く、設定した入力波は種々のFAに適用できるものと考えられる。

\section{9. おわりに}

FAの耐震性の簡易評価方法の骨子となる耐震性評価用入力波とし て、 $2 \mathrm{~Hz} 3$ 波の正弦波を基本とした入力波を設定した経過，結果を述 ベた。また、設定した入力波を再現し、比較的小規模な実験でFAの 耐震性を簡易に評価できる振動台を例示した。

設定した入力波と例示した振動台を用いたFAの耐震性評価の手順 は、以下の通りである。

(1)振動台上に評価対象 FAの試験体を設置する。さらに、設置した試 験体上に、必要に応じて所定の重鍾を載荷する。

(2)評価対象FAに要求される耐震性能に応じて、入力波の加速度振幅 を設定する。例えば、最大加速度 $\mathrm{a}$ の実地震波などに対する耐震性 を評価する場合には、入力波の加速度振幅を a とする。

(3)(2)で加速度振幅を設定した入力波で試験体を加振し、加振後の試験 体の状態に基つ゚いて評価対象 FA の耐震性を評価する。

以上であるが、試験体上に載荷する重鍾やその載荷方法の詳細、振 動台上に設置した試験体の周囲の拘束方法、あるいは加振後の試験体 の状热の判定基準など、耐震性の簡易評価方法の設定にあたってはさ らに検討しなければならない課題が多数残されていることを、付け加 える。

\section{碀辞}

本研究に対し有益な御助言をいただくとともに、試験の実施や簡易 振動台の設計，試作にあたり種々御配虑，御協力いただいたフリーア クセスフロア工業会の関係各位に、深く謝意を表します。また、油圧 式振動台での試験に御協力いただいた財団法人建材試験センターの関 係各位に、御礼申し上げます。

\section{参考文献}

1)横山 裕, 片木詩子: 非構造床の耐震性評価方法に関する基磁的研究，日本 建築学会大会学術講演梗概集, A - 1, pp. 217 ～218, 2002.8

2)横山 裕，片木詩子：非構造床の耐震性䛨価方法に閣する基礎的研究，日本 建筑学会大会学術講演梗概集, A - 1, pp.839 840, 2004.8

3)社団法人公共建築協会 : 建劉材料・設備機材等品質性能評価事業 建築材料 等評価名簿 平成 11 年版, 1999

4)JIS A 1450 フリーアクセスフロア構成材試験方法, 2003.2 